\title{
KERUSAKAN HUTAN DAN LINGKUNGAN HIDUP DARI PEMBANGUNAN DAN PERTUMBUHAN PENDUDUK (STUDI KASUS DI KABUPATEN POLEWALI MANDAR)
}

\author{
Sukadji Sarbi*
}

\begin{abstract}
Polewali Mandar has a wealth of tropical forests, to the extent of reaching 72.814 ha. As a forest ecosystem, it plays a very important role for human development and health. Therefore, a healthy forest is needed that can support human life.Human growth and development, has provided various negative impacts on forest ecosystems. Forest management that has been applied has not been able to maintain the optimal function of forests, the more damaged forests. Many economic interests dominate the implementation of forest management. In order to maintain and restore forest functions optimally from various threats that increasingly necessary reorientation to change the practices of forest resource management and the environment wisely, so that the crisis destruction of forests and the environment can be controlled.To the community and various parties related to the management of forest resources and the environment needed awareness to embody the moral and ethics of the environment.
\end{abstract}

Keywords: saving forests and the environment.

\section{PENDAHULUAN}

Hutan bukan hanya sekumpulan individu pohon, tepai merupakan suatu masyarakat tumbuhan yang kompleks, yang terdiri selain dari pohon, juga semak-semak tumbuhan bawah, jasat renik tanah, dan fauna lainnya. Mereka menjadi satu kesatuan yang satu sama lainnya terikat dalam hubungan ketergantungan.

*) Prodi PPKn, Universitas Al Asyariah Mandar

E-mail: sukadjisarbi50@gmail.com 
Untuk dapat dikategorikan sebagai hutan, sekelompok pohon-pohon harus memiliki tajuk-tajuk yang cukup rapat, sehingga merangsang pemangkasan secara alami, dengan cara menaungi ranting dan bahan dibagian bawah dan menghasilakan tumpukan bahan dan menghasilkan tumpukan bahan organik/serasah yang sudah terurai maupun yang belum terurai di atas tanah meneral. Disamping itu, di dalam ekosistem hutan juga terdapat unsur-unsur lain yang berasosiasi antara lain tumbuhan yang kecil dan berbagai bentuk kehidupan fauna.

Dalam rangka pengembangan kemampuan pengelolaan hutan dan linngkungan hidup juga adanya berbagai kerusakan hutan dan lingkungan yang saat ini dirasakan semakin meningkat, karena laju degredasi sumberdaya hutan dan lingkungan jauh lebih tinggi jika dibandingkan dengan laju upaya kita sampai dengan saat ini untuk melakukan perlindungan dan pelestarian alam.

Berbagai kerusakan sumberdaya alam yang paling menonjol adalah kerusakan hutan dan lingkungan hidup di Kabupaten Polewali Mandar cenderung terus meningkat, dampak negatifnya pun secara luas terhadap kualitas lingkungan semakin dirasakan bersama. Hal ini sangat terkait dengan semakin meningkatnya jumlah manusia dan pembangunan.

Sukaji Sarbi. 2013. 25 mengemukakan bahwa karena peningkatan jumlah manusia ini, diikuti pula dengan laju peningkatan konsumsi, dimana ekplotasi terhadap berbagai sumber alam termasuk hutan pun terus meningkat, hingga saat ini kita semakin sulit untuk membendung kerusakan hutan dan lingkungan hidup. Dilain pihak, terutama karena 
kemampuan kita untuk menahan laju kerusakan tersebut sangat rendah, jika dibandingkan dengan kekuatan-kekuatan perusak. Berbagai peraturan perundangan pun sulit ditegakkan bagi berbagai pelanggar atau perusak hutan dan lingkungan hidup.

Kita dapat pahami bahwa secara akademis, kita juga telah berhasil mengenali berbagai penyebabnya. Namun, dalam kenyataanya tetap sulit untuk mengemplementasikan pencegahan ataupun penanggulangan kerusakan hutan dan lingkungan tersebut. Hasanu Simon. 2010.12. mengemukakan bahwa proses tersebut terus berlanjut yaitu kecepatan laju permudaan semakin tidak dapat mengimbangi laju penebangan, sehingga umur hutan sekunder yang ditebang sudah dibawah daur tehnik. Karena memang akar pernasalahannya sangat rumit, menyangkut berbagai aspek sisial, ekonomi, budaya maupun politik dari berbagai lapisan masyarakat yang beranekaragam. Salah satu yang banyak disoroti di daerah ini adalah faktor kemiskinan, persoalan perut ini memang harus segera dipecahkan secara komprehensip, sehingga tepat jika agenda pengelolaan hutan dan lingkungan hidup dikaitkan dengan pengentasan kemiskinan.

Disamping itu, salah satu sebab utamanya adalah sulitnya merobah moral pelaku ekonomi dan lajunya pembangunan. Sering kali mereka hanya berorientasi kepada keuntungan ekonomi jangka pendek, yang sangat bertentangan dengan tujuan keuntungan ekologi lingkungan jangka panjang, terutama bagi perlindungan hutan dan lingkungannya. Hutan-hutan alam yang memiliki keragaman hayati yang tinggi diubah menjadi hutan sejenis ataupun tanaman perkebunan yang cukup luas. 
Kegiatan eksplotasi hutan dilakukan tanpa perhitungan kemampuannya, bahkan penebangan pohon yang tidak tebang pilih, sehingga sulit untuk memperoleh hutan lestari.

\section{METODE PENELITIAN}

\section{Keadaan Umum Kabupaten Polewali Mandar}

Sebelum dinamai Polewali Mandar, daerah ini bernama Kabupaten Polewali Mamasa yang secara administratif berada dalam Wilayah Provinsi Sulawesi Selatan. Setelah daerah ini dimekarkan dengan berdirinya Kabupaten Mamasa sebagai kabupaten tersendiri, maka nama Polewali Mamasa pun diganti menjadi Polewali Mandar dengan luas wilayah 2.022,30 $\mathrm{Km}^{2}$ (Permendagri No.56 Tahun 2015). Nama kabupaten ini resmi digunakan dalam proses administrasi pemerintahan sejak tanggal 1 Januari 2006 setelah ditetapkan dalam bentuk Peraturan Pemerintah Nomor 74 Tahun 2005 tanggal 27 Desember 2005 tentang perubahan nama Kabupaten Polewali Mamasa menjadi Kabupaten Polewali Mandar.

Daerah ini jika dikaji posisi geografisnya, maka berdasarkan data Badan Pusat Statistik Kabupaten Polewali Mandar Tahun 2017, dengan jumlah penduduk 455.572 jiwa dengan pertumbuhan penduduk 1,96 persen dan ibukotanya Polewali. Daerah ini. terletak antara 20.40.' 3032' LS dan 1180. 40' - 1190. 32' BT mempunyai luas Wilayah 2. 022,30 km² $^{2}$ terdiri atas 16 Kecamatan, 26 Kelurahan dan 132 Desa dengan batas-batas wilayah sebagai berikut: (a). Sebelah Selatan berbatasan dengan laut Selat Makassar, (b). Sebelah Utara berbatasan dengan 
Kabupaten Mamasa, (c). Sebelah Timur berbatasan dengan Kabupaten Pinrang dan (d) Sebelah Barat berbatasan dengan Kabupaten Majene.

\section{Data dan Potensi Hutan}

Mengenai luas hutan Kabupaten Polewali Mandar yang ada saat ini. berdasarkan data pada Kantor Dinas Kehutanan dan Lingkungan Hidup Polewali Mandar 2017 menunjukkan bahwa luas kawasan hutan Kabupaten Polewali Mandar seluas 72.814 ha. Sesuai dengan fungsinya, kawasan hutan di Daerah ini dibagi ; (a) Hutan lindung 55.375 ha. Pemerintah Daerah telah menetapkan hutan lindung diperuntukan bagi pengendalian banjir dan erosi. (b) Hutan produksi 16,539 ha. Hutan produksi dikelola untuk produsi hasil hasil hutan baik maupun non kayu sedangkan (c) Hutan konservasi 900 ha (cagar alam, taman wisata, suaka margasatwa) ditetapkan bagi kepentingan perlindungan dan pelestarian keanekaragaman hayati, rekreasi dan pariwisata serta ilmu pengetahuan.

Potensi hutan sangat berbeda dari satu daerah dengan daerah lainnya, hal ini sangat terkait dengan zona-zona biogeografinya. Khusus untuk zona Kabupaten Polewali Mandar yang kaya hasil hutan misalnya kayu dan rotan yaitu: eboni, laban atau betti dan rotan. Produksi hutan, khususnya kaju dan rotan merupakan sumber dari pendapatan dan perdagangan masyarakat didaerah ini. Sebagian besar menjadi bahan industri lokal dari masyarakat sekitar kawasan hutan yang dengan ketergantungannya dari hutan. Dari sudut ekonomi sub sektor industi kehutanan secara umum diperoleh kayu gergajian sebanyak 2.025.238 $\mathrm{m}^{3}$ / tahun dan dari hutan sekunder diperoleh dalam 
bentuk rotan sebanyak $1.375 \mathrm{~m}^{3}$./ tahun. ( Kantor Kehutanan dan LH Kab. Polman 2017).

\section{HASIL PENELITIAN DAN PEMBAHASAN}

Kita pahami bersama secara akademik bahwa berbagai diskusi, seminar, bahkan workshop tentang konservasi hutan dan lingkungan hidup telah banyak dilakukan selama 10 tahun terakhir. Ini menandakan semakin meningkatnya kepedulian kita terhadap pentingnya hutan dan lingkungan hidup, bahkan kitapun sudah mengenali dengan baik berbagai akar permasalahan semakin merosotnya kondisi hutan dan lingkungan hidup. Berdasarkan pemantauan lapangan kenyataan yang terjadi dengan adanya kerusakan-kerusakan hutan dan lingkungan hidup di Kabupaten Polewali Mandar ini merupakan akibat dari aktivitas manusia yang tidak memperhatikan aspek ekologi seperti :

a. Alih pungsi hutan menjadi : ladang kakao, tanaman palawija dan jahe.

b. Peladang berpindah-pindah.

c. Pengelolaan hutan yang kurang bijaksana.

d. Penebangan pohon untuk keperluan bahan bangunan (kantor, rumah, mobiler).

e. Penebagangan pohon untuk diperjual belikan pada pedagang kayu.

f. Penebangan pohon untuk bahan kayu bakar.

Keputusan mereka mempunyai dampak yang sangat luas terhadap kerusakan hutan dan lingkungan hidup. Saat ini masih terdapat suatu polemik antara konsep pembangunan secara umum dengan upaya 
pengembangan sumberdaya hutan dan lingkungan, dimana pada prinsipnya tidak saling tolak belakang. Berdasarkan data pada Kantor Dinas Kehutanan dan Lingkungan Hidup Kabupaten Polewali Mandar tahun 2017 mengenai luas lahan kritis dalam kawasan, akibatnya kegiatan manusia berdampak buruk terhadap hutan dan lingkungannya sebagaimana yang terlihat pada Tabel. 1.

Tabel 1. Luas Lahan Kritis Dalam Kawasan Hutan

\begin{tabular}{|c|c|l|c|}
\hline No. & Area Kawasan & \multicolumn{1}{|c|}{ Keadaan } & Luas (hektar) \\
\hline 1. & Hutan & Potensial Krtitis & 32.530 \\
\hline 2. & Hatan & Agak Kritis & 13.608 \\
\hline 3. & Hutan & Kritis & 42,886 \\
\hline 4. & Hutan & Sangat Kritis & 28,56 \\
\hline
\end{tabular}

Sedangkan mengenai luas lahan kritis di luar kawasan, akibatnya kegiatan manusia berdampak buruk terhadap hutan dan lingkungannya sebagaimana yang terlihat pada Tabel. 2

Tabel 2. Luas Lahan Kritis di luar Kawasan Hutan

\begin{tabular}{|c|c|l|c|}
\hline No & Area Kawasan & \multicolumn{1}{|c|}{ Keadaan } & Luas (hektar) \\
\hline 1. & Hutan & Tidak Krtitis & 21.161 .53 \\
\hline 2. & Hatan & Potensial Kritis & 22.783 .07 \\
\hline
\end{tabular}




\begin{tabular}{|c|c|l|c|}
\hline 3. & Hutan & Agak Kritis & $25,366.35$ \\
\hline 4. & Hutan & Kritis & 45.408 .62 \\
\hline 5. & Hutan & Sangat kritis & 28,56 \\
\hline
\end{tabular}

Berdasarkan data pada Badan Penanggulangan Bencana Daerah (BPBD) Kabupaten Polewali Mandar tahun 2017 bencana alam pada 2 (dua) tahun terakhir hal ini sebagaimana yang terlihat pada Tabel 3.

Tabel 3. Lokasi dan Jenis Kerusakan Bencana Alam di Kabupaten Polewali Mandar

\begin{tabular}{|c|c|c|c|c|c|c|}
\hline \multirow[t]{2}{*}{ No. } & \multirow[t]{2}{*}{ Tanggal } & \multicolumn{2}{|c|}{ Lokasi } & \multirow[t]{2}{*}{$\begin{array}{c}\text { Jenis } \\
\text { Bencana } \\
\text { Alam }\end{array}$} & \multicolumn{2}{|c|}{$\begin{array}{c}\text { Jenis Kerusakan } \\
\text { \& Keadaan } \\
\text { Rumah }\end{array}$} \\
\hline & & Desa & Kec. & & Ringan & Berat \\
\hline 1. & $\begin{array}{l}12-2- \\
2016\end{array}$ & $\begin{array}{l}\text { Kanusuan } \\
\text { g }\end{array}$ & Luyo & Longsor & 2 & 5 \\
\hline 2. & $\begin{array}{l}21-2- \\
2016\end{array}$ & Anreapi & Anreapi & Longsor & 5 & 4 \\
\hline 3. & $\begin{array}{l}17-3- \\
2016\end{array}$ & $\begin{array}{l}\text { Papandan } \\
\text { gan }\end{array}$ & Anreapi & Longsor & 7 & 6 \\
\hline 4. & $\begin{array}{l}30-3- \\
2016\end{array}$ & Kurra & Tapango & Longsor & 3 & 2 \\
\hline
\end{tabular}


Jika kerusakan hutan ini terus berlangsung, maka akan terjadi di daerah ini krisis lingkungan yang berkepanjangan, kemerosotan produktivitas lahan pangan yang luar biasa dan menurunya ketersedian air dari hutan. Di Desa Papandangan bekerja sama dengan Mahasiswa pencinta lingkungan (Mapala) Universtas Al Asyariah Mandar, Dandim 1428 Kabupaten Polewali Mandar telah melakukan penanaman pohon jati putih, sengon dan pohon kemiri sebanyak 1.750. pohon di lokasi area longsor dan daerah yang rawan lonsor di Desa Papandangan.

Pepohonan dalam ekosistem hutan mempunyai peranan penting tidak hanya dalam siklus air, akan tetapi juga berperan dalam pengawetan tanah dan dalam siklus air pohon merupakan pemindahan air hujan ke tanah melalui proses penahan sementara air hujan oleh tajuk pohon, sehingga tidak langsung menimpah tanah. Penahanan air hujan oleh tajuk pohon akan mengurangi resiko gangguan terhadap pori-pori tanah, sehingga aliran permukaan dapat dikendalikan.

Dalam rangka melindungi dan melestarikan hutan dan lingkungan hidup, Dinas Kehutanan dan Lingkungan Hidup Kabupaten Polewali Mandar tidak lagi memberikan izin baru kepada pengusaha - pengusaha kakao, kelapa sawit atau pengusaha lainnya yang mau investasi membuka usaha yang berkaitan dengan kehutanan. Bagi lahan-lahan yang mengalami kerusakan ataupun lahan kritis dilakukan rehabilitasi dan reboisasi hutan. Rehabilitasi hutan dan lingkungan hidup dimaksudkan untuk memulihkan, mempertahankan, dan meningkatkan fungsi hutan dan lingkungan hidup, sehingga daya dukung, produksivitas, dan peranannya dalam mendukung sisten penyangga kehidupan tetap 
terjaga. Dimana rehabilitasi hutan dan lingkungan hidup diselenggarakan melalui kegiatan reboisasi, penghijauan, pemeliharaan, pengayaan tanaman, atau penerapan teknik konservasi tanah secara vegetatif dan pada lahan kritis dan lahan tidak produktif.

Dalam rangka pengelolaan sumberdaya hutan dan lingkungan hidup secara benar sangat terkait dengan kemampuan berbagai institusi di Daerah Kabupaten Polewali Mandar seperti kebijakan (aturan termasuk norma dan etika) organisasi dan tentunya sebagai inti pokoknya adalah sumberdaya manusia yang mampu menjalakan semua organisasi, aturan, norma ataupun penegakan hukum yang berlaku dalam konteks pembangunan yang berwawasan lingkungan. Komponen-komponen institusi daerah sangat perlu untuk terus ditingkatkan kemampuannya, sehingga dapat mempertautkan kepentingan generasi mendatang dengan kepentingan generasi sekarang dalam melaksanakan pembangunan. Tersimpul disini adanya keharusan mewariskan sumber-sumber alam inclusit sumberdaya hutan dan lingkungan secara lestari kepada generasi mendatang agar dapat dikelola secara sambung sinambung generasi demi gerasi sepanjang zaman.

\section{SIMPULAN}

Adapun kesimpulan yang dapat di ambil dari hasil penelitian dan pembahasan adalah

1. Kabupaten Polewali Mandar memiliki sumberdaya alam hutan topis yang sangat penting peranannya dalam pertumbuhan pembangunan dan fungsi ekologis secara lokal, nasional maupun secara global. 
2. Seiring dengan laju pertubuhan penduduk 1,44 persen, maka hutan dan lingkungan hidup mengalami kerusakan yang luar biasa, hingga tahun 2017 ini luas hutan yang sangat kritis mencapai 28,56 ha.

3. Berbagai program rehabilitasi dan pengelolan hutan lestari dan lingkungan hidup yang dilakukan oleh Pemerintah Daerah Kabuapten Polewali Mandar belum memperoleh hasil secara signnifikan dalam memperbaiki dan mencegah kerusakan hutan dan lingkungan hidup.

\section{SARAN DAN REKOMENDASI}

Diharapkan hasil penelitian ini dapat memberikan masukan kepada pemerintah daerah Kabupaten Polewali mandar dalam mengambil kebijakan terkait lingkungan hidup dan diharapkan ada tindak lanjut dari penelitian ini.

\section{DAFTAR PUSTAKA}

Badan Pusat Statistik (BPS) Kabupaten Polewali Mandar Tahun 2017.

Badan Penanggulangan Bencana Daerah (BPBD) Kabupaten Polewali Mandar Tahun 2017.

Undang Undang RI Nomor. 41 Tahun 1999 Tentang Kehutanan.

Undang- Undang RI Nomor. 32 Tahun 2009 Tentang Perlindungan dan Pengelolaan Lingkungan Hidup.

Kantor Dinas Kehutanan dan Lingkungan Hidup Kabupaten Polewali Mandar Tahun 2016.

Sukaji Sarbi. 2006. Strategi Pengembangan Kapasitas Pengelolaan Lingkungan Hidup di Era Otonomi Daerah Kabupaten Polewali Mandar. Penerbit. PPLH. Lembaga Penelitian Universitas Udayana Bali. 
.2012. Kontribusi Perguruan Tinggi Terhadap Lingkungan Hidup. Penerbit. Kretakuta. Makassar. .2013. Lingkungan Hidup. Penerbit. Kretakua. Makassar. .2017. Sistem Sumberdaya Alam dan Lingkungan Hidup. Penerbit UMI Press. Makassar.

Hasanu Simon.2010. Sumberdaya Hutan. Seleban Timur UH. III/548 Yogjakarta 55167.

Indriyanto. 2006. Ekologi Hutan. Penerbit. Bumi Aksara. Jakarta. 